NUKHBATUL 'ULUM : Jurnal Bidang Kajian Islam

Vol. 4, No. 1 (2018) : Hal. 51-60

Website: https://journal.stiba.ac.id

ISSN : 2685-7537 (online) 2338-5251 (Printed)

\title{
POLA KOMUNIKASI DA'IYAH DALAM PEMBINAAN KEAGAMAAN DI MUSLIMAH WAHDAH ISLAMIYAH DAERAH MAKASSAR
}

\section{Hijrayanti Sari}

Sekolah Tinggi Ilmu Islam dan Bahasa Arab (STIBA) Makassar,

Jl. Inspeksi PAM Manggala-Antang Makassar

E-Mail: hijrahmuin@gmail.com

\begin{tabular}{ll}
\hline Keywords : & \multicolumn{1}{c}{ ABSTRACT } \\
\cline { 2 - 3 } $\begin{array}{l}\text { religious } \\
\text { communicational pattern. }\end{array}$ & $\begin{array}{l}\text { The aim of this research is to identify the communicational pattern } \\
\text { applied by Muslimah of Wabdab Islamiyah in the effort of religious } \\
\text { coaching. This research applies qualitative and descriptive method. } \\
\text { Method of collecting respondents are purposive sampling where the } \\
\text { samples are 10 female preachers of Islamic study groups. The data are } \\
\text { acquired from interview, observation and documentation. The result } \\
\text { shows that religious coaching conducted by the female preachers of } \\
\text { Wabdah Islamiyah is in the context of small group communication } \\
\text { with informative and persuasive technique. Communicational pattern } \\
\text { used is the wheel pattern and starpattern. }\end{array}$ \\
\hline
\end{tabular}




\section{PENDAHULUAN}

Perkembangan dakwah Islam semakin menunjukkan peningkatan pada beberapa tahun terakhir ini. Semangat mengkaji Islam ini terlihat pada kegiatan-kegiatan keislaman yang terlaksana setiap harinya di lingkungan kota Makassar baik itu di sekolah, kampus, kecamatan maupun di instansi-intansi pemerintah. Adapun pengamalan nilai-nilai Islam dapat dilihat dengan semakin banyaknya muslimah yang menggunakan bijab sesuai dengan ketentuan-ketentuan dalam Al Qur'an dan Sunnah, jama'ah sholat yang juga bertambah pada setiap waktu-waktu sholat. Hal ini tentunya atas taufik dari Allah Subhanahu wa Ta'ala dan atas kerja keras para aktifis dakwah dalam pembinaan keagamaan kaum muslimin.

Pembinaan keagamaan terdiri dari dua kata yaitu pembinaan dan keagamaan. Pembinaan juga dapat diartikan: " bantuan dari seseorang atau sekelompok orang yang ditujukan kepada orang atau sekelompok orang lain melalui materi pembinaan dengan tujuan dapat mengembangkan kemampuan, sehingga tercapai apa yang diharapkan. Dari beberapa definisi di atas, dapat dipahami bahwa dalam pembinaan terdapat unsur tujuan, materi, proses, cara, pembaharuan, dan tindakan pembinaan. Selain itu, untuk melaksanakan kegiatan pembinaan diperlukan adanya perencanaan, pengorganisasian dan pengendalian. ${ }^{1}$ Sedangkan pengertian dari keagamaan itu sendiri ialah, bahwa keagamaan

1http://infodanpengertian.blogspot.co.id 2016/02/pengertian-pembinaan-menurut-paraahli.html (09 Maret 2018)

${ }^{2}$ Hasan Alwi, Kamus Bahasa Indonesia. (Jakarta: Balai Pustaka.2007), h.12. berasal dari kata agama yang kemudian mendapat awalan "ke" dan akhiran "an". Sehingga membentuk kata baru yaitu "keagamaan". Jadi keagamaan di sini mempunyai arti "segenap kepercayaan (kepada Tuhan) serta dengan ajaran kebaikan dan kewajibankewajiban yang bertalian dengan kepercayaan itu".

Dari rumusan di atas, yang dimaksud dengan pembinaan keagamaan adalah suatu usaha untuk membimbing dan mempertahankan serta mengembangkan atau menyempurnakan dalam segala seginya, baik segi akidah, segi ibadah dan segi akhlak. ${ }^{3}$

Wahdah Islamiyah adalah sebuah Organisasi Massa (Ormas) Islam yang mendasarkan pemahaman dan amaliyahnya pada Al Qur'an dan As Sunnah sesuai pemahaman As Salaf Ash-Shalih (Manhaj Ahlussunnah Wal Jamaah). Organisasi ini bergerak di bidang da'wah, pendidikan, sosial, kewanitaan, informasi, kesehatan dan lingkungan hidup. ${ }^{4}$

Muslimah Wahdah Islamiyah adalah salah satu bagian dalam jajaran organisasi Wahdah Islamiyah yang mempunyai tugas melakukan pembinaan kepada muslimah. Dengan pesan dakwah yang berasaskan $\mathrm{Al}$ Qur'an dan Assunnah dengan menitikberatkan pemahaman Shalafussholeh dikenal oleh masyarakat sebagai gerakan dakwah yang tegas dalam menentang ibadah-ibadah yang tidak pernah diamalkan oleh Rasulullah Sallallahu 'Alaihi wasallam dan para Shahabat atau biasa disebut dengan dakwah salafiyyah. Daiyah Muslimah

\footnotetext{
3Bisri Mustofa, Arba'in Nawawi. (Rembang: Menara Kudus, 1375 H), h.7-9.

4 http://wahdah.or.id/sejarah-berdirimanhai/ (9 Maret 2018)
} 
Wahdah Islamiyah dikenal dengan jilbab besar, bercadar dan kegiatankegiatan dakwah yang diadakan selalu berpisah dengan laki-laki. Berdasarkan observasi yang diadakan oleh peneliti di kota Makassar menilai bahwa jama'ah Muslimah Wahdah cukup besar. Terbukti dengan beberapa kegiatan akbar yang diadakan oleh Muslimah Wahdah Islamiyah pada tanggal 14 April 2015 dan 17 April 2016 di Celebes Convention Centre Makassar mampu menghadirkan peserta kegiatan sampai dengan jumlah sepuluh ribu muslimah.

Berdasarkan latar belakang diatas maka peneliti ingin mengetahui pola komunikasi yang digunakan dan dikembangkan oleh Da'iyah Muslimah Wahdah Islamiyah di kota Makassar dalam pembinaan keislaman jama'ahnya. Penelitian ini menggunakan pendekatan kualitatif deskriptif. Penelitian kualitatif adalah penelitian yang bersifat interpretif (menggunakan penafsiran) yang melibatkan banyak metode, dalam menelaah masalah penelitiannya. Sesuai dengan prinsip epistomologisnya, peneliti kualitatif lazim menelaah halhal yang berada dalam lingkungan alamiahnya, berusaha memahami atau menafsirkan fenomena berdasarkan makna-makna yang orang berikan kepada hal-hal tersebut (Denzin dan Lincoln, 1998:3). ${ }^{5}$

Penelitian deskriptif sesungguhnya dapat dikatakan sebagai penelitian yang diarahkan pada pengukuran yang cermat terhadap suatu fenomena sosial tertentu. Penelitian harus menggunakan diri sebagai instrument. Mengikuti asumsi kultural sekaligus mengikuti data. ${ }^{6}$

5 Dedi Mulyana.Solatun, Metode Penelitian Komunikasi, (Bandung:Rosda, 2013),h .5 .
Teknik penelitian yang digunakana adalah observasi dan wawancara. Tehnik pemilihan responden dilakukan dengan sengaja (purpossif) yaitu 10 daiyah halaqah (kelompok) pengajian (tarbiyab) mahasiswi. Pemilihan sampling ini dilatabelakangi karena daya kritis mahasiswa yang lebih tinggi dibandingkan kalangan siswi sekolah ataupun muslimah yang sudah bekerja.

\section{PEMBAHASAN}

$\begin{array}{ccr}\text { Komunikasi } & \text { dan } & \text { Pola } \\ \text { Komunikasi } & & \\ \text { Komunikasi } & \text { merupakan }\end{array}$
kebutuhan fundamental bagi manusia. Komunikasi merupakan alat transformasi pesan, warisan ilmu dan nilai. Karenanya pengetahuan dan kemampuan komunikasi sering menjadi kemampuan penunjang utama keberhasilan sebuah misi.

Sebuah defenisi yang dibuat oleh kelompok sarjana komunikasi yang mengkhususkan diri pada studi komunikasi antarmanusia (human communication) bahwa komunikasi adalah suatu transaksi, proses simbolik yang menghendaki orang-orang mengatur lingkungannya dengan membangun hubungan antarsesamanusia melalui pertukaran informasi untuk menguatkan sikap dan tingkah laku orang lain serta berusaha mengubah sikap dan tingkah laku itu. Harold D Lasswel juga mendefenisikan bahwa cara yang tepat untuk menerangkan suatu tindakan komunikasi ialah menjawab pertanyaan siapa yang menyampaikan, apa yang disampaikan, melalui apa disampaiakan, kepada siapa dan apa

6 Julia Brannen, Memandu Metode Penelitian Kualitatif dan Kuantitatif., (Cet. IV: Yogyakarta: Pustaka Pelajar, 2002), h. 11 
pengaruhnya. Perkembangan terakhir adalah munculnya pandangan dari Joseph de Vito, K. Sereno dan Erika Vora yang menilai faktor lingkungan merupakan unsur yang tidak kalah pentingnya dalam mendukung terjadinya proses komunikasi. ${ }^{7}$

Unsur-unsur komunikasi yang disebutkan oleh para ahli diatas jika dijabarkan menjadi sebagai berikut:

1. Sumber adalah semua peristiwa komunikasi akan melibatkan sumber sebagai pembuat atau pengirim informasi. Dalam komunikasi antarmanusia, sumber bisa terdiri dari satu orang, tetapi bisa juga dalam bentuk kelompok misalnya partai, organisasi atau lembaga. Sumber sering disebut pengirim, komunikator atau dalam bahasa Inggrisnya disebut source, sender atau encoder.

2. Pesan adalah sesuatu yang disampaikan dengan cara tatap muka atau melalui media komunikasi. Isinya berupa ilmu pengetahuan, hiburan, informasi, nasihat atau propaganda. Dalam bahasa Inggris pesan biasanya diterjemahkan dengan kata message, content atau information.

3. Media adalah alat yang digunakan untuk memudahkan pesan dari sumber kepada penerima. Terdapat beberapa pendapat mengenai saluran atau media. Ada yang menilai bahwa media bisa bermacam-macam

bentuknya., misalnya dalam komunikasi interpersonal pancaindera dianggap sebagai media komunikasi. Selain indra manusia, ada juga saluran komunikasi seperti telepon, surat, telegram ayng digolongkan sebagai media komunikasi interpersonal.

4. Penerima adalah pihak yang menjadi sasaran pesan yang dikirim oleh sumber. Penerima bisa terdiri satu orang atau lebih bisa dalam bentuk kelompok, partai atau negara.

5. Pengaruh adalah perbedaan antara apa yang dipikirkan, dirasakan, dan dilakukan oleh penerima sebelum dan sesudah menerima pesan. Pengaruh ini terjadi pada pengetahuan, sikap dan tingkah laku seseorang (De Fleur, 1982). Oleh karena itu, pengaruh bisa juga diartikan perubahan atau penguatan keyakinan dan pengatahuan, sikap, dan tindakan seseorang sebagai akibat menerima pesan.

6. Tanggapan balik, ada yang beranggapan bahwa umpan balik sebenarnya adalah salah satu bentuk daripada pengaruh yang berasal dari unsur lain seperti pesan dan media, meski pesan belum sampai pada penerima.

7. Lingkungan adaalah faktofaktor tertentu yang dapat mempengaruhi jalannya 
komunikasi. Faktor ini dapat digolongkan atas empat macam, yakni lingkungan fisik, lingkungan sosial budaya, lingkungan psikologis dan dimensi waktu. ${ }^{8}$

Untuk membuat bidang komunikasi dan proses komunikasi lebih mudah dipahami maka para ilmuwan komunikasi membuat konteks komunikasi. Konteks adalah lingkungan di mana komunikasi itu terjadi.

1. Komunikasi intrapersonal. Adalah komunikasi yang terjadi dengan diri sendiri. Ini merupakan dialog internal dan bahkan dapat terjadi bahakan saat bersama dengan orang lain. Kita semua memiliki dialog internal dan suara-suara di dalam batin ini dapat bervariasi dari satu orang ke orang lainnya. Komunikasi mcam ini juga melibatkan banyak penilaian akan perilaku orang lain. Selain membuat penilaian terhadap orang lain, komunikasi intrapersonal juga memberikan kesempatan bagi komunikator untuk menilai dirinya sendiri.

2. Komunikasi interpersonal. Merujuk pada komunikasi yang terjadi secara langsung antara dua orang. Konteks interpersonal terdiri atas beberapa subkonteks yang terkait. Peneliti komunikasi interpersonal telah mempelajari mengenai keluarga, pernikahan usia panjang, hubungan dokter dan pasien, dan relasi di lingkungan kerja. Selain itu peneliti juga tertarik dengan isu dan tema seperti kompetensi, pembukaan diri, kekuasaan, gosip, kesukaan, ketertarikan, emosi dan sebagainya.

3. Komunikasi kelompok kecil. Kelompok kecil (small group) terdiri atas beberapa orang yang bekerja sama untuk mencapai tujuan bersama. Penelitian mengenai kelompok kecil berfokus pada kelompok kerja, berlawanan dengan pertemanan dan kelompok keluarga dalam konteks komunikasi interpersonal. Orang yang dipengaruhi oleh keberadaan orang lain. Contohnya, beberapa kelompok kecil sangat cohesive, yaitu memiliki tingkat kebersamaan yang tinggi dan ikatan yang kuat. Sifat cohesive ini akan mempengaruhi apakah kelompok ini dapat berfungsi dengan efektif dan efisien. Selain itu konteks kelompok kecil memberikan kesempatan pada individual untuk mendapatkan berbagai perspektif terhadap suatu persoalan.

4. Komunikasi organisasi. Konteks komunikasi ini mencakup komunikasi 
yang terjadi di dalam dan di antara lingkungan yang besar dan luas. Jenis komunikasi ini sangat bervariasi karena komunikasi organisasi juga meliputi komunikasi interpersonal, kesempatan berbicara di depan publik, kelompok kecil dan komunikasi dengan menggunakan media. Oleh karenanya, organisasi terdiri atas kelompok yang diarahkan oleh tujuan yang sama.

5. Komunikasi publik. Konteks yang kelima dikenal sebagai konteks komunikasi publik (public communication) atau penyebaran informasi dari satu orang kepada banyak orang.

6. Konteks keenam adalah komunikasi massa yang menyasar khalayak dalam umlah besar. Konteks komunikasi massa berbeda dengan kontes lain karea komunikasi yang terjadi biasanya lebih terkendali dan terbatas.

7. Komunikasi lintas budaya. Konteks yang terakhir merujuk pada komunikasi antara individu-individu yang latar belakang budayanya berbeda. Individu-individu ini tidak harus berasal dari negara yang berbeda. ${ }^{9}$

Dalam penyampaian pesan dari komunikator kepada komunikan dibutuhkan seni penyampaian.

${ }^{9}$ Richard West. Lynn H Turner, Pengantar Teori Komunikasi: Analisis dan Aplikasi, Ed 3.,

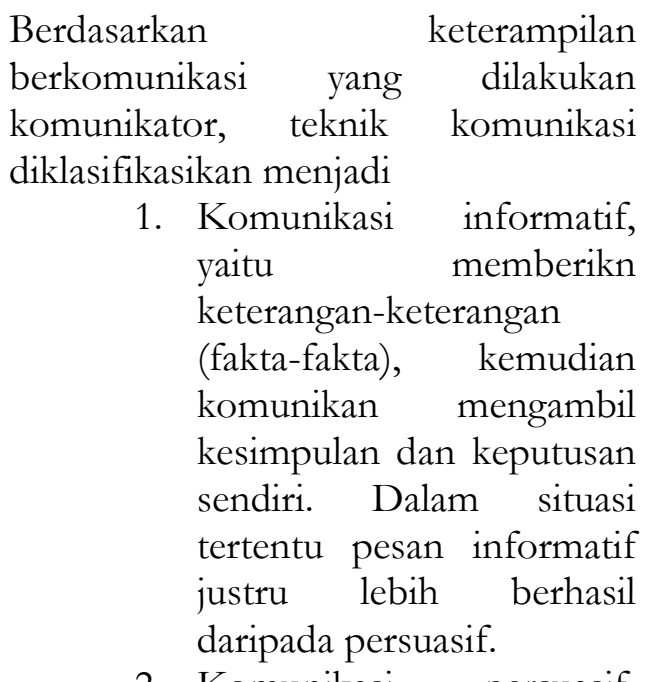

2. Komunikasi persuasif, yaitu berisikan bujukan, yakni membangkitkan pengertian dan kesadaran manusia bahwa apa yang kita sampaikan akan memberikan perubahan sikap, tetapi perubahan ini atas kehendak sendiri (bukan paksaan). Perubahan tersebut diterima atas kesadaran sendiri.

3. Komunikasi

instruktif/koersif, yaitu penyampaian pesan yang bersifat memaksa dengan menggunakan sanksisanksi apabila tidak terlaksana.

4. Hubungan manusiawi, yaitu apabila ditinjau dari ilmu komunikasi, hubungan manusiawi ini termasuk ke dalam komunikasi interpersonal sebab berlangsung pada

Buku 1., (Jakarta:Penerbit Salemba Humanika, 2007), h. 34-42 
umumnya antara dua orang secara dialogis. ${ }^{10}$

Menurut H. A. Widjaja, ada empat pola komunikasi yaitu, komunikasi pola roda, pola rantai, pola lingkaran dan pola bindatng (Mudjoto). Keempat pola tersebut dapat dilihat pada gambar berikut:

Gambar. 1

Pola Komunikasi Roda

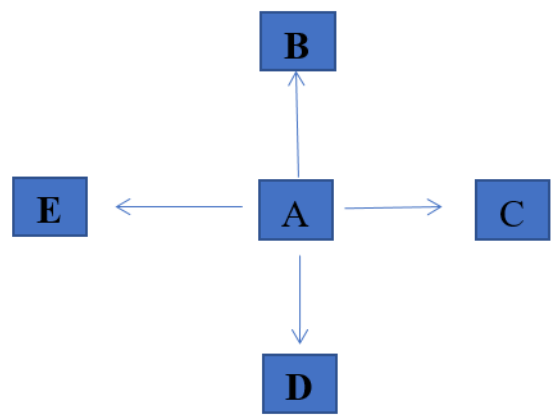

Gambar. 2

Pola Komunikasi Rantai

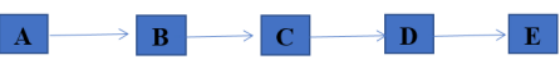

Gambar. 3

Pola Komunikasi lingkaran

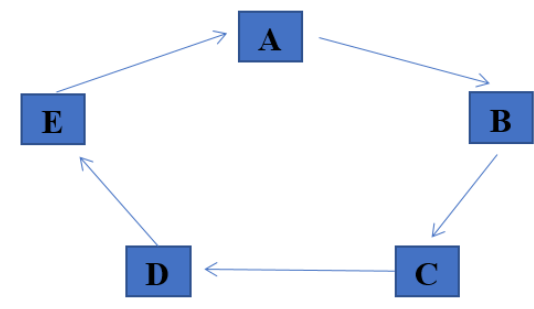

10 H.A.W.Widjaja, IImu Komunikasi Pengantar Studi, (Cet 3; Jakarta:Bumi Aksara, 1997), h. 32
Gambar. 4

Pola Komunikasi Bintang

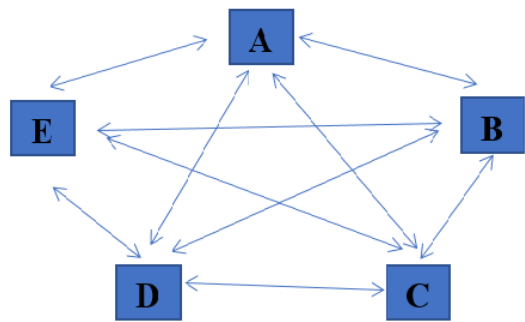

Pola roda adalah pola yang mengarahkan seluruh informasi kepada individu yang menduduki posisi sentral. Orang yang dalam posisi sentral menerima kontak dan informasi yang disediakan oleh anggota lainnya dan memecahkan masalah dengan saran dan persetujuan anggota lainnya. Pola rantai adalah pola yang mengarahkan seseorang berkomunikasi pada seseorang yang lain kepada anggota yang lainnya dan anggota seterusnya. Pola lingkaran memungkinkan semua anggota berkomunikasi satu dengan yang lainnya hanya melalui sejenis sistem pengulangan pesan. Tidak seorang anggota pun yang dapat berhubungan langsung dengan semua anggota lainnya, demikian pula tidak ada anggota yang memiliki akses langsung untuk semua informasi yang diperlukan untuk memecahkan persoalan. Sedangkan pola bintang adalah pola yang memungkinkan semua anggota bisa berkomunikasi dengan semua anggota lainnya. ${ }^{11}$

Pembinaan keagamaan yang dilakukan oleh Muslimah Wahdah Islamiyah dengan 2 metode yaitu metode umum dan metode khusus. Metode umum seperti seminar

${ }^{11}$ H.A.W.Widjaja, Ilmu Komunikasi Pengantar Studi, (edisi revisi; Jakarta: PT. Rineka Cipta, 2000), h. 102-103 
keislaman, tablik akbar dan talk show. Metode umum ini adalah kajian keislaman yang sifatnya kondisional, biasanya untuk menjawab atau mendiskusikan sebuah fenomena. Sedangkan metode khusus adalah kajian keislaman yang dilakukan setiap pekan dengan materi yang terstruktur. Pada metode khusus inilah proses pembinaan keagamaan berlangsung secara efektif.

Allah berfirman dalam surah an-Nahl: 16/125, "Serulah manusia kepada jalan Tuhan-Mu dengan hikmah dan pengajaran yang baik, dan berdebatlah dengan mereka dengan cara yang baik. Sesungguhnya Tuhanmu, Dia-lah yang lebih Mengetahui siapa yang sesat dari jalan-Nya dan Dialah yang lebih Mengetahui siapa yang mendapat petunjuk.

Metode pembinaan keislaman dalam organisasi Wahdah Islamiyah dikenal dengan nama Tarbiyah. Dalam bahasa arab tarbiyah adalah pendidikan. Dalam ruang lingkup Wahdah Islamiyah, tarbiyah adalah metode pembinaan keislaman secara tertata rapi dengan membuat programprogram yang lengkap yang dibangun di atas prinsip-prinsip ajaran Islam (seperti adanya program hafalan $\mathrm{Al}$ Qur'an, amal jama'i, dan yang lainya, dimana program ini dibuat diatas prinsip-prinsip ajaran Islam yang menyeluruh yang bertujuan untuk membentuk pribadi-pribadi muslim yang ideal. ${ }^{12}$

Proses tarbiyah di bina oleh seorang murobbi atau murobbiyah. Murobbi atau murobbiyah adalah da'i atau da'iyah Wahdah Islamiyah yang telah melewati beberapa tahap

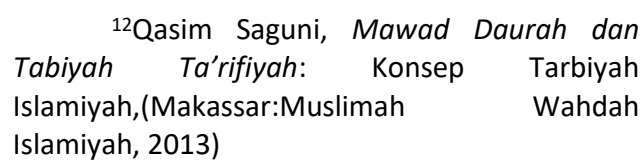

pembinaan keislaman secara intensif di Wahdah Islamiyah. Murobbi atau murobbiyah bertanggungjawab terhadap program program halaqah. Kelompok tarbiyah dalam konteks komunikasi merupakan komunikasi kelompok kecil. Jumlah anggota halaqah tarbiyah terdiri dari 5 sampai 15 orang.

Dalam konteks komunikasi kelompok kecil, ada perdebatan mengenai jumlah orang yang membentuk kelompok kecil. Beberapa peneliti berpendapat bahwa jumlah maksimal dalam kelompok kecil adalah lima sampai tujuh orang, sementara yang lain tidak memberikan batasan jumlah. Tetapi hampir semuanya setuju bahwa paling tidak harus ada tiga orang dalam sebuah kelompok kecil (Schultz, 1996). ${ }^{13}$

Rangkaian kegiatan selama tarbiyah berlangsung adalah pertama diawali dengan pembacaan Al Qur'an oleh seluruh anggota tarbiyah secara bergantian. Selama anggota tarbiyah membaca Al Qur'an, murobbiyah memberikan perbaikan jika ada anggota tarbiyah yang membaca dengan tidak tepat sesuai dengan kaidah membaca Al Quran. Kegiatan kedua, murobbiyah memberikan materi keislaman dan anggota tarbiyah mendengarkan. Kegiatan ketiga adalah problem solving. Pada kegiatan ini anggota tarbiyah bebas memberikan pertanyaan terkait dengan materi atau diluar materi yang dipaparkan oleh murobbiyah. Setiap 2 bulan sekali diadakan "hari bersama". Hari bersama ini adalah kegiatan tarbiyah yang diadakan dengan nuansa berbeda. Bisa berupa outdoor ataupun indoor. Inti

${ }^{13}$ Richard West. Lynn H Turner, Pengantar Teori Komunikasi: Analisis dan Aplikasi, Ed 3., Buku 1., (Jakarta:Penerbit Salemba Humanika, 2007), h. 37 
kegiatan hari bersama ini adalah untuk meningkatkan ikatan ukhuwah antar anggota ukhuwah,

Tehnik penyampaian pesan yang digunakan oleh murobbiyah pada saat mengoreksi bacaan Al Qur'an dan penyampaian materi keislaman adalah kolaborasi teknik komunikasi informatif dan persuasif. Seperti yang telah dijelaskan diatas bahwa komunikasi informatif yaitu memberikan keterangan-keterangan (fakta-fakta), kemudian komunikan/anggota tarbiyah mengambil kesimpulan dan keputusan sendiri. Persuasif, yaitu berisikan bujukan, yakni membangkitkan pengertian dan kesadaran manusia bahwa apa yang kita sampaikan akan memberikan perubahan sikap, tetapi perubahan ini atas kehendak sendiri (bukan paksaan). Perubahan tersebut diterima atas kesadaran sendiri. Murobbiyah memberikan materi keislaman disertakan dengan dalil-dalil yang berasal dari Al Quran, As Sunnah dan kisah-kisah nabi, shalafussholeh dan ulama salaf.

Metode komunikasi yang digunakan pada saat tarbiyah adalah pola komunikasi dua arah. Yaitu komunikator dan komunikan menjadi saling tukar fungsi dalam menjalani fungsi mereka. Pada tahap pertama Murobbiyah memberikan pesan bertindak sebagai komunikator dan anggota tarbiyah sebagai komunikan. Pada tahap selanjutnya anggota tarbiyah bertindak sebagai komunikator dan Murobbiyah sebagai komunikan. Namun hakekatnya yang memulai percakapan adalah komunikator utama. Komunikator utama dalam konteks ini adalah Murobbiyah mempunyai tujuan tertentu melalui proses komunikasi tersebut. Prosesnya dialogis, serta umpan balik terjadi secara langsung. Pola komunikasi yang digunakan adalah pola roda dan pola bintang. Pola roda adalah pola yang mengarahkan seluruh informasi kepada individu yang menduduki posisi sentral. Posisi sentral dalam tarbiyah adalah Murobbiyah. Orang yang dalam posisi sentral (murobbiyah) menerima kontak dan informasi yang disediakan oleh anggota lainnya dan memecahkan masalah dengan saran dan persetujuan anggota lainnya. Sedangkan pola bintang adalah pola yang memungkinkan semua anggota bisa berkomunikasi dengan semua anggota lainnya. Pola ini terlihat pada saat problem solving di akhir pertemuan tarbiyah dan kegiatan "hari bersama".

\section{PENUTUP}

Berdasarkan uraian diatas dan hasil temuan peneliti mengenai pola komunikasi dalam pembinaan keislaman di Muslimah Wahdah Islamiyah maka dapat ditarik kesimpulan bahwa pembinaan keislaman yang dilakukan oleh daiyah Muslimah Wahdah Islamiyah adalah dalam konteks komunikasi kelompok kecil dengan menggunakan teknik komunikasi informatif dan persuasif. Pola komunikasi yang digunakan adalah pola roda dan pola bintang.

\section{DAFTAR PUSTAKA}

Alwi, Hasan. Kamus Bahasa Indonesia. Jakarta: Balai Pustaka.2007.

Brannen, Julia. Memandu Metode Penelitian Kualitatif dan Kuantitatif., Cet. IV: Yogyakarta: Pustaka Pelajar. 2002.

Cangara, Hafied. Pengantar Ilmu Komunikasi. edisi revisi; Jakarta: Pt Raja Grafindo Persada. 2011. 
NUKHBATUL 'ULUM : Jurnal Bidang Kajian Islam

Vol. 4, No. 1 (2018) : Hal. 51-60

Website: https://journal.stiba.ac.id

ISSN : 2685-7537 (online) 2338-5251 (Printed)

Mulyana, Dedi .Solatun. Metode Penelitian Komunikasi. Bandung:Rosda. 2013.

Mustofa, Bisri. Arba'in Nawawi. Rembang: Menara Kudus. 1375 H.

Saguni, Qasim. Mawad Daurah dan Tabiyah Ta'rifiyab: Konsep Tarbiyah Islamiyah. Makassar:Muslimah Wahdah Islamiyah. 2013.

West, Richard. Turner, Lynn H, Pengantar Teori Komunikasi: Analisis dan Aplikasi. Ed 3., Buku 1.,Jakarta:Penerbit Salemba Humanika. 2007.

Widjaja, H.A.W. Ilmu Komunikasi Pengantar Studi. Cet 3; Jakarta:Bumi Aksara. 1997.

Widjaja, H.A.W..Ilmu Komunikasi Pengantar Studi. edisi revisi; Jakarta: PT. Rineka Cipta. 2000.

http://id.m.wikipedia.org/wiki/Wahd ah_Islamiyah

http://infodanpengertian.blogspot.co. id/2016/02/pengertianpembinaan-menurut-paraahli.html

http://wahdah.or.id/sejarah-berdirimanhaj/

http://kbbi.web.id/bina 